\title{
Teachers' Evaluation of the Omani EFL Basic Education Textbooks
}

\author{
Salma Al-Humaidi* \\ Sultan Qaboos University, Oman \\ Received: 5/2/2014 \\ Revised: 7/5/2014 \\ Accepted: 13/5/2014
}

The purpose of this study was two-fold: first, to develop a tool for evaluating the EFL textbooks in the Omani Basic Education schools, and second, to involve teachers in the evaluation process. Three research questions were asked: (1) What are the relevant criteria for evaluating the Omani EFL textbooks used in Basic Education schools? (2) To what extent do the textbooks match the evaluative criteria? (3) Does teachers' evaluation of textbooks vary according to gender and experience? An evaluation checklist including 42 criteria in question form was developed and validated. In fall 2008, 73 EFL teachers ( 35 males and 38 females) from Muscat and Al-Dakhiliya regions used the checklist to evaluate the grade 10 textbooks of the Basic Education stage. Data analysis showed that the evaluative criteria are reflected to some extent in the textbooks and that there was no statistically significant difference in teachers' evaluations of the textbooks due to gender and experience. It was recommended that EFL textbooks be evaluated and teachers be involved in the evaluation process. In addition, the Colleges of Education should offer a course on textbook evaluation.

Keywords: teachers' evaluation, basic education, Sultanate of Oman.

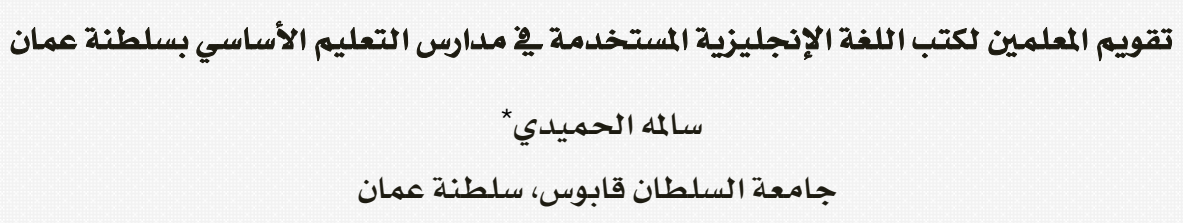

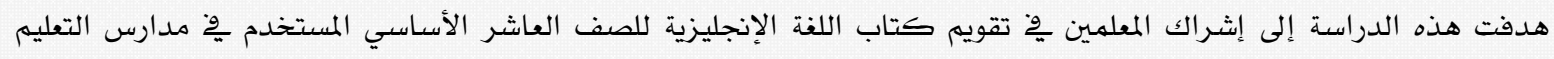

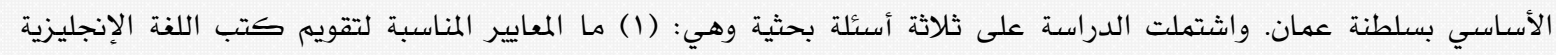
المستخدمة وِّدارس التعليم الأساسي بسلطنة عمان؟ (Y) إلى أي مدى تعتبر هذه المعايير مطابقة لكتب اللغة الإنجليزية المستخدمة وْْ مدارس التعليم الأسـاسي بسلطنة عمان من وجهة نظر المعلمين؟ (r) هل يختلف تقويم المعلمين لكتب اللفة الإنجليزية باختلاف الجنس والمؤهل وسنوات الخبرة وِّ التدريس؟ ولجمع البيانات قام الباحث بإعداد قائمة بالمعايير المناسبة لعملية التقويم تتكون من هن ثلاثة محاور اشتملت على اثنين وأربعين معيارا أو سؤالا بالإضافة إلى سؤال مفتوح. وقد قام ثلاثة وسبعون معلما باستخدام هذه

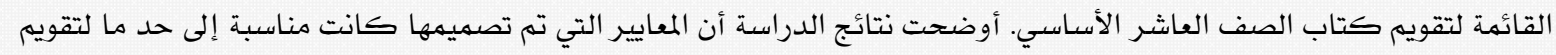

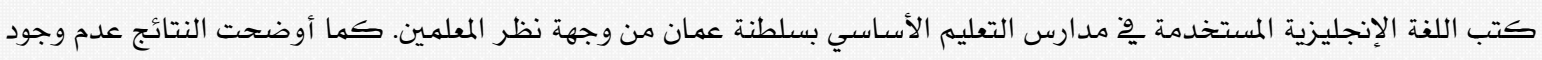
فرق وِ تقويم المعلمين للكتب باختلاف الجنس وسنوات الخبرة. وقد أوصت الدراسة بضرورة قيام وزارة التربية والتعليم بتقويم

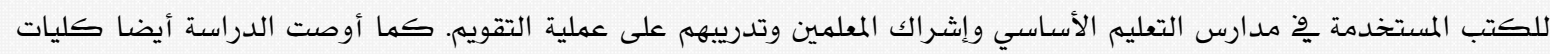

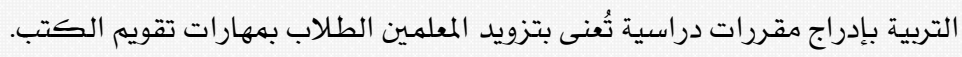

* shumaidi@squ.edu.om

$$
\text { الككلمات المفتاحية: تقويم المعلمين، التعليم الأسـاسي، سلطنة عمان. }
$$


In 1997, the Omani Ministry of Education introduced a new educational system in the government schools. It was the Basic Education (henceforth $\mathrm{BE}$ ), which replaced the General Education system in most schools. BE was intended to provide ten years of the same education for all children in Oman. It is divided into two cycles: cycle one includes grades 1 to 4 and cycle two includes grades 5 to 10 . BE provides basic educational needs such as information, knowledge, skills, and values that enable the learners to continue education and training according to their tendencies, aptitudes, interests and abilities (Basic Education in Oman, 1996).

In the BE system, there is a locally designed series of textbooks entitled 'English for $\mathrm{Me}^{\prime}$ (henceforth EFM). The academic year 2006/ 2007 witnessed the completion of the BE system in the Omani public schools. Grade ten is the last level in the BE system. The textbook of Grade ten aims to consolidate and strengthen English learned in earlier grades.

The purpose of this study was two-fold: (1) to develop a tool for evaluating the EFL textbooks in the Omani Basic Education schools and (2) to involve teachers in the evaluation process. Towards this end, it attempted to answer three questions: (1) What are the relevant criteria for evaluating the Omani EFL textbooks used in Basic Education schools?, (2) To what extent do the EFL textbooks match the evaluative criteria?, and (3) Does teachers' evaluation of EFL textbooks vary according to gender, and length of teaching experience?

\section{Review of Related literature}

\section{What is a Textbook?}

Many writers and educational specialists discussed the importance of textbooks (e.g. Gómez-Rodríguez, 2010, and Hutchinson, \& Torres, 1994). Some writers have defined the term 'textbook' differently. However, they all agree that a textbook is a teaching tool and a manual of instruction in a specific subject, especially one for use in schools or colleges (Collins Cobuild English Dictionary, 1995; The Free Dictionary, 2014; English Dictionary, 2007). In addition, it is a book that contains presentation of the principles of a subject and a literary work relevant to the study of that subject and differentiates it from other books by some characteristics such as being acceptable, attractive to hold attention, well presented, lavishly illustrated, up to date and interesting for students (Portway and Lane, 1997).

\section{Justification for Textbook Evaluation}

Textbook evaluation is not a simple process as it requires certain professional skills and professional evaluators in addition to a special administration of the process. Zabawa (2001: 161 ) indicates that "... textbook evaluation is to a great extent based on a subjective judgment". Results of evaluation are necessary in order to take right decisions for changing or developing textbooks.

Different ELT specialists such as textbook writers, teachers and administrators, need to be involved in a holistic process of textbook evaluation. Once a decision is made to evaluate a textbook, it has to be conducted jointly by the whole education team. Such a holistic process of evaluation includes teachers, who are the most important components in the educational process. Tomlinson (2005) provides some important questions to do textbook evaluation: (1) Does the textbook have a weak or strong link to the overall program?, and (2) What are the changes and developments re quired for improving it? Lamie (1999), in line with Tomlison, indicates that a textbook can be regarded as a curriculum in itself if it receives a systematic evaluation.

Hutchinson and Waters (1987) also describe it as a straight forward, analytical matching process; matching needs to available solutions. Hutchinson and Waters think that the evaluation of EFL textbooks is a matter of judging their fitness for the purpose for which they are designed. EFL textbook evaluation also helps designers to make decisions for developing the textbook as well as raising the teachers' awareness of the materials they use and helping them reflect on their daily teaching experience. Cunningsworth (1995) recommends that when evaluating a textbook, attention should be given to the context in which this textbook is used. Thus, EFL textbook evaluation is a necessary process that shows how the textbook is suitable for a particular group of learners (see also Lawrence, 2011).

\section{EFL Teachers as Textbook Evaluators}

Based on their daily use of textbooks and their knowledge about the learners' needs, interests 
and proficiency levels, teachers can provide scientific, objective judgements about the usefulness and relevance of the textbooks. According to Price-Machado (cited in Gomes de Matos 2000), several specialists should be involved in the process of textbook evaluation. The teacher is the most important element in this process as $\mathrm{s} /$ he uses the textbook for a long period. To make an effective use of a textbook, attention must be paid to the teacher's comments about it. The only way to obtain this information is through careful evaluation of textbooks and other curriculum materials by teachers as well as involving other specialists such as designers, curriculum developers, etc. Teachers need to be well-informed about the textbooks they teach.

It is recommended that teachers be acquainted with the curriculum, involved in the design of the textbook and given an overview of each syllabus. This would provide teachers with a theoretical and practical view of the curriculum and its methodology. More specifically, teachers need to determine the extent to which a textbook focuses on and is aligned with a set of significant, age-appropriate student learning goals that the educational system has identified as integral to the understanding of and progress in a particular academic subject. Further, Kulm, Roseman, and Treistman (1999) indicate that teachers should be involved in assessing how well a textbook's instructional design effectively supports the attainment of specified learning goals. Along similar lines, Gomes de Matos (2000), maintain that in order to be competent in textbook evaluation, EFL teachers should be given preservice training in how to evaluate textbooks and instructional materials. This is because textbook evaluation for in-service teachers provides them with the skills necessary to judge the quality of the different textbooks they encounter throughout their teaching career.

\section{A pproaches to EFL Textbook Evaluation}

Ellis (1997:2) describes two types of evaluation: 'predictive evaluation', which helps to select a particular textbook for a target group of learners, and 'retrospective evaluation', which reports information about an ongoing textbook or one that has just been covered. Retrospective evaluation helps to decide whether the evaluated textbook should continue, be developed or even changed completely. Most of the EFL educationalists and researchers have common views of EFL textbook evaluation such as 'why, how, when and who' to evaluate textbooks.

Tucker (cited in Ansary \& Babaii, 2002) developed an approach for textbook evaluation. This approach consists of three components or dimensions. The first dimension includes a set of criteria that are used to evaluate the basic linguistic, psychological, and pedagogical principles of the textbook. These criteria are divided into two types: internal criteria and external criteria. Internal criteria are related to the language and content of the textbook. External criteria inform a broader view of the textbook. The second dimension includes a rating scheme, which helps evaluators to assess the comparative weightings of the textbook's merits. The third dimension includes a chart, which can be used to compare the evaluator's results of the textbook with any other model of evaluation in order to facilitate and display the evaluator's judgment.

Brown (1997) suggests an approach to textbook evaluation that consists of three dimensions. Dimension one directs the evaluator to consider and have some knowledge of the 'system' in which the textbook is included for the purpose of having well informed evaluation. The system, besides the textbook, includes other materials such as the teacher's guide, visual, audio and video materials. These materials have a substantial impact on the overall ease of textbook implementation and its quality. Dimension two leads the evaluator to assess the content of the textbook. This includes weighing what the four language skills are, and assessing exercises and activities and how much they are motivating to students. This process also requires the evaluator to consider the practice of the grammar items and functions in each unit of the textbook. Further, the evaluator should look at the amount of artwork in each lesson, e.g. colour of the pages, the amount of content on each page, and the design and presentation of the lessons. Dimension three guides the evaluator to examine the relationship and consistency of all the parts of the textbook. It also requires the evaluator to explore the ways in which the textbook helps the teacher to move quickly and easily from part to part while using the textbook in the classroom.

In the Omani context, Al Amri (2003) proposed a plan for evaluating textbooks. This 
plan consists of four processes. In the first process, evaluators should assess the representation of the authors' aims in the textbook. They should also evaluate the appropriateness of the content, structure, the four language skills and the relevance of activities to the students' level. In the second process, evaluators should observe the students' performance while using the textbook in the classroom. This is important in order to identify the strengths and weaknesses of the textbook and discover any problem(s) that students may face. In this process, evaluators are also advised to judge the teachers' way of applying the textbook. The third process defines the people who are required to evaluate the textbook. These are either 'insider' or 'outsider' evaluators. Insider evaluators are those who use the textbook in the teaching/ learning process such as teachers and students. Outsiders are not related to the use of the textbook, but they are required to evaluate it in terms of their experience of textbooks design and implementation. In the fourth process, evaluators collect additional information about the textbook from teachers, students and the teaching and learning context.

Dow (2004) lists a number of necessary considerations for teachers to be aware of in order to guide them through the textbook evaluation process in terms of the suitability of textbooks to their students. These considerations come under four categories or dimensions which form an approach to textbook evaluation. These dimensions are: (1) language background of students, (2) proficiency level of students in English, (3) learning goals of the textbook, and (4) preferred teaching/ learning approaches. Under the first dimension, teachers should have some background information about the students' native language, their abilities to read and write in their native language and the setting of their learning. Under the second dimension, teachers should know the level of their students in English in order to define their proficiency. Teachers should also define and evaluate the different levels of students and their abilities for using the four language skills. Under the third dimension, teachers should determine and evaluate the students' need of English: what type of communication skills they need English for and the kind of English they need. Under the fourth dimension, teachers, while evaluating a textbook, should focus on the suitable me thods of teaching and learning for the students and what approaches of language learning they prefer.

\section{Related Studies}

To the best knowledge of the researchers, no in-house EFL textbook evaluation process has been conducted by teachers in the Omani ELT context. The two Omani studies did not deal with textbook evaluation in particular; but described the experience of the Ministry of Education in evaluating the English language curriculum in general and investigated the teachers' opinions of involving them in the process of curriculum evaluation (see AI Mushaifri 2006; Al-Hosni 2006).

The purpose of this study (AI M ushaifri, 2006) was to document the attempts of the Ministry of Education in evaluating all curricula used in BE schools including the English curriculum. This researcher analyzed the techniques and instruments which were used by the Ministry in evaluating the curriculum. These techniques and documents involved the use of documentary evidence from annual publications of the Ministry, field visits, reports, books, journals and questionnaires. To analyze these documents, the researcher relied on his personal experience as a curriculum officer. The re searcher found that there was no clear plan for the curriculum evaluation and the effective participation of teachers in this process was rare. Therefore, it was suggested that the Ministry should establish a comprehensive strategy for curriculum evaluation based on the new BE curriculum reform. AI Mushaifri (2006) also recommended that sufficient training should be provided to those who are required to evaluate the curriculum, especially the teachers.

The purpose of the second study (AI-Hosni, 2006) was to explore the teachers' perceptions of involving them in the process of curriculum development and evaluation. Al-Hosni selected four hundred and twenty two male and female teachers as a purposive sample out of a total population of two thousands one hundred and twenty eight teachers from all regions of Oman. To collect the required data, the researcher used a questionnaire of two dimensions including current practices related to teacher involvement and teachers' perceptions of their involvement in different curricu- 
lum activities. Al-Hosni found that most EFL Omani teachers perceive that the bottom-up participation in curriculum evaluation was very important. Al-Hosni (2006), also found that Omani EFL teachers had the desire to be involved in the process of curriculum evaluation. Consequently, it was reported that there is a need to involve them in this process and that curriculum designers need to seek teachers' feedback while reprinting or developing the materials because the failure of many innovations could be due to the gap between designers and implementers. Both of these two studies revealed that there was insufficient evaluation of curriculum in general and of EFL textbooks in particular either through topdown or bottom-up approaches.

Results of the two studies pave the way to the current study which aims at conducting an ongoing process of EFL textbook evaluation as well as involving teachers in this process. It should also be noted that other researchers investigated and examined textbooks from different perspectives according to the purpose of the evaluation. For instance, some researchers evaluated the overall and general features and organization of the textbooks and their appropriateness to the context and the inclusion of global common issues shared by all people all over the world with reference to other supplementary materials (see Hernandez, 1986; Al-Hajailan, 1999; Yen, 2000).

Still other textbook studies focussed on the evaluation of the EFL textbooks in terms of the language level, integration of the four language skills in the textbooks, tackling grammar and vocabulary, and performance of activities and tasks by students (see Peyawary, 1992; Decio, 1996; Al-A kloby, 2001). Still another different line of textbooks research traced teachers' perceptions of EFL curricula and textbooks and other related issues such as the teachers' involvement and role in the process of textbook evaluation (see Song 1991, and AI-Darwish, 2006).

\section{Subjects}

\section{METHOD}

A convenient sample including 73 teachers (35 males and 38 females) was taken from the Capital Region (Muscat) and the Interior Region (Dakhiliya). The participants taught grade ten during the academic years 2006/ 2007 and 2007-2008 in two regions of the country (Muscat and Dakhiliya) due to the availability of a large number of teachers who had enough years of teaching experience with BE textbooks.

Table 1

Frequency and percentages of

gender, qualifications, and experiences of teachers

\begin{tabular}{llcr}
\hline & & Frequency & Percent \\
\hline \multirow{3}{*}{ Gender } & Male & 35 & 47.9 \\
& Female & 38 & 52.1 \\
& Total & 73 & 100.0 \\
\hline \multirow{5}{*}{ Qualification } & BA & 73 & 100.0 \\
& Master & 0 & 0 \\
& PhD & 0 & 0 \\
& Total & 73 & 100.0 \\
\hline \multirow{5}{*}{ Experience } & $1-5$ & 12 & 16.4 \\
& $6-10$ & 20 & 27.4 \\
& $11-15$ & 14 & 19.2 \\
& $16-20$ & 14 & 19.2 \\
& Morethan 20 & 13 & 17.8 \\
& Total & 73 & 100.0 \\
\hline
\end{tabular}

Table 1 shows that all teachers hold a BA de gree. They have different years of experiences, which are classified into five groups. Group 610 years of experience includes the highest number of teachers (20). They represent $27.4 \%$ of the total sample. Group 1-5 years of experience includes the lowest number of teachers (12). They represent $16.4 \%$. Groups $11-15$ and 16-20 years of experience include the same number of teachers while 13 teachers had more than 20 years of experience.

Evaluation was limited to only one set of textbooks (Grade Ten) that is used in BE. Focus on Grade Ten was because it is the last level in BE and involves a large amount of language input, a high level of grammar practice, more activities, and further practice of the four language skills especially writing.

\section{INSTRUMENT AND PROCEDURES}

After critically reviewing the currently available evaluation checklists (See Williams, 1981 \& 1983; Mathews, 1985; Breen and Candlin, 1987; Dougill, 1987; Cisar, 2002; Miekley, 2005) and the Omani Minstry of Education documents such as the Basic Education Curriculum Framework and the guidelines of designing and writing in-house EFL textbooks in Oman, the checklist used in the present study was developed. As shown in appendix (1), it includes 42 items categorized into three dimensions: (1) language input, (2) activities and tasks, and (3) non-textual components. These dimensions were designed along a 4-point scale The levels of the scale were: not at all, to a little extent, to some extent, and to a large extent. The aim of the checklist was to help the 
teachers evaluate the Omani EFL textbooks used in BE schools in general and the grade 10 textbooks in particular. The checklist also includes an open-ended question which aims to explore teachers' opinions about the usefulness of involving teachers in the process of textbook evaluation.

In order to establish the validity of the checklist, it was given to ten ELT specialists from the College of Education at Sultan Qaboos University and the Department of English Language Curriculum at the Ministry of Education for validation. They were asked to assess the relevance and clarity of each item in the checklist, provide the necessary modifications and suggest any additional items. It was found that most of the jury members- except two- supported including the question form instead of statements which the original checklist included. Accordingly, the items were formulated in the form of questions beginning with 'To what extent.?' (see appendix 1). Once the validity of the checklist was established, it was pilot-tested to establish its reliability. A sample of 15 male and female English teachers in Muscat region used the checklist to evaluate grade ten BE textbooks (A and B). The reliability of the checklist was analyzed using Cronbach's alpha and was found to be 0.76 . In fall 2008 , the evaluation process took place where the checklist was applied to the subjects of the study.

\section{D ata analysis and discussion}

\section{Relevant criteria for evaluating the O mani EFL textbooks}

The identification of relevant criteria for the evaluation of Omani EFL textbooks is represented in the developed checklist which includes 42 items. Those items were considered as the criteria required for evaluating the textbooks. The scale points were To a large extent, To some extent, To a little extent, and $\mathrm{N}$ ot at all. They were given the grades 4, 3, 2, and 1 respectively (SeeA ppendix 1).

\section{II.Teachers' evaluation of the Omani EFL textbooks}

In order to analyze the data required for answering the $2^{\text {nd }}$ question of the study, "To W hat extent do the textbooks match the evaluative criteria?", the interval 4-point scale was changed into a continuous scale including the following cut-points:
1. From 1 to less than $\mathbf{1 . 7 5}$ means that teachers see that the evaluative criteria in the checklist are not reflected in the textbooks.

2. From 1.75 to less than 2.5 means that teachers see that the evaluative criteria in the checklist are reflected to a little extent in the textbooks.

3. From 2.5 to less than 3.25 means that teachers think that the evaluative criteria in the checklist are reflected to some extent in the textbooks.

4. From 3.25 to less than 4 means that teachers see that the evaluative criteria in the checklist are reflected to a large extent in the textbooks.

\section{Descriptive Statistics for Q uestion Two}

\begin{tabular}{lcc}
\multicolumn{3}{c}{$\begin{array}{c}\text { Table } 2 \\
\text { M eans and standard deviations of the three main } \\
\text { dimensions }\end{array}$} \\
\hline Dimension & Mean & SD \\
\hline Non-textual components & 3.17 & .59 \\
Language input & 2.82 & .783 \\
Activities and skills & 2.62 & .745 \\
\hline
\end{tabular}

Results in table 2 reveal that the "Non-textual components" dimension got the highest mean value (3.17) followed by the "Language input" and the "Activities and skills" dimensions which got similar means values (2.82 and 2.62 respectively). Despite this difference and according to the specified continuous scale above, all mean values of the three main dimensions fall in the third range (2.5-3.25) which means that teachers think the evaluative criteria in the checklist are reflected to some extent in the textbooks. Following is a more detailed analysis of each dimension.

\section{Evaluation of dimension one: language input}

As mentioned earlier, the criteria in the first dimension were categorized into four subdimensions: topics, vocabulary, grammar and language skills. Tables 3 displays the means and standard deviations of teachers' responses to the 25 questions. 
Table 3

Means and standard deviations of language input in grade ten textbooks (topics, vocabulary, grammar, the four language skills)

\begin{tabular}{|c|c|c|c|}
\hline Topics in textbooks & $\mathrm{N}$ & Mean & SD \\
\hline Does the CB include a variety of topics? & 72 & 3.50 & .712 \\
\hline \multirow{2}{*}{$\begin{array}{l}\text { Do the units include a variety of text types such as conversations, interviews, } \\
\text { e-mails, instructions, descriptions, stories, radio extracts, songs and poems? } \\
\text { Do the topics contain multi-cultural perspectives? }\end{array}$} & 72 & 3.44 & 647 \\
\hline & 71 & 3.12 & .715 \\
\hline A re the topics interesting to students? & 72 & 3.05 & .578 \\
\hline Are the topics relevant to the students' age? & 73 & 3.02 & .763 \\
\hline Are the topics appropriate to our culture? & 73 & 3.01 & .950 \\
\hline $\begin{array}{l}\text { Do the units have a variety of language functions such as making excuses, } \\
\text { making requests, asking and defining ... etc? }\end{array}$ & 73 & 3.00 & .781 \\
\hline $\begin{array}{l}\text { Do the topics allow for the development of activities similar to those that } \\
\text { found in real life situations outside the classroom? }\end{array}$ & 73 & 2.97 & .744 \\
\hline
\end{tabular}

\begin{tabular}{|c|c|c|c|}
\hline \multicolumn{4}{|l|}{ Vocabulary in textbooks } \\
\hline $\begin{array}{l}\text { Does the vocabulary appear in a variety of ways for example in a context, } \\
\text { sentence completion, sentence formation... etc? }\end{array}$ & 73 & 3.10 & .657 \\
\hline Is there a variety of active as well as passive vocabulary use in the $\mathrm{CB} \& \mathrm{SB}$ ? & 72 & 3.00 & .82 \\
\hline Are the phoneme boxes and the word lists hel pful? & 73 & 2.93 & .871 \\
\hline Is the vocabulary load reasonable? & 73 & 2.55 & 1.000 \\
\hline Is the vocabulary recycled in different units? & 72 & 2.53 & .765 \\
\hline \multicolumn{4}{|l|}{ G rammar in textbooks } \\
\hline $\begin{array}{l}\text { Do the self-study pages at the end of each unit in the SB consolidate the } \\
\text { grammatical items that students covered before? }\end{array}$ & 72 & 3.30 & .816 \\
\hline $\begin{array}{l}\text { Do the language focus boxes in the SB provide clear explanations for the } \\
\text { rules? }\end{array}$ & 73 & 3.05 & .684 \\
\hline $\begin{array}{l}\text { Does the grammar reference included in the SB enhance previously learned } \\
\text { grammatical items? }\end{array}$ & 73 & 3.04 & .840 \\
\hline Are there lessons in which grammar is tackled implicitly? & 72 & 2.55 & .902 \\
\hline $\begin{array}{l}\text { Are there enough examples applying the grammatical items in the language } \\
\text { focus boxes in the SB? }\end{array}$ & 73 & 2.50 & .669 \\
\hline \multicolumn{4}{|l|}{ The four language skills in textbooks } \\
\hline Do the reading texts in the $\mathrm{CB}$ include authentic language? & 69 & 3.17 & .617 \\
\hline Are the four language skills presented in units integratively? & 72 & 3.13 & .810 \\
\hline $\begin{array}{l}\text { Are there real life issues in the CB and SB, which encourage students to } \\
\text { speak? }\end{array}$ & 73 & 2.94 & .761 \\
\hline $\begin{array}{l}\text { Are the four language skills practiced through a variety of text types such as } \\
\text { stories, descriptions, dialogues, songs and/ or poems? }\end{array}$ & 73 & 2.91 & .795 \\
\hline Is there enough input for each language skill in each unit? & 73 & 2.90 & .748 \\
\hline $\begin{array}{l}\text { Are the listening materials in the CB \& SB enough to enhance the listening } \\
\text { skill? }\end{array}$ & 72 & 2.75 & .960 \\
\hline $\begin{array}{l}\text { Do the writing scripts in the CB provide students with enough help for im- } \\
\text { proving their own writings? }\end{array}$ & 73 & 2.01 & .889 \\
\hline
\end{tabular}

\section{Topics in EFL textbooks}

Table 3 displays the teachers' responses to the eight questions asked to evaluate the topics in the textbooks. The mean values of the responses of the teachers to the questions range between 2.9 and 3.5. This means that most of the criteria are reflected to some extent in the textbook. However, the highest mean value (3.50) is given to the question Does the class book (CB) include a variety of topics? Whereas the lowest mean value (2.97) is given to question 4. From these descriptive results, it can be concluded that the EFL teachers involved in this evaluative study think that the EFL textbooks include a variety of interesting and re levant topics, which help teachers develop authentic tasks and activities. Furthermore, although these topics include a multi-cultural perspective, they are relevant to the Omani culture. 


\section{Vocabulary in EFL textbooks}

Vocabulary includes five criteria/ questions for evaluating vocabulary in the textbooks. The mean values (in Table 3) of the responses of the teachers to the questions range from 2.5 to 3.1. In light of the previously mentioned cutpoints, this means that all of the criteria are reflected to some extent in the textbooks. It was also found that vocabulary is used in a variety of ways and recycled in the different units in the textbook. Based on these results, it can be concluded that teachers think that the textbooks include a variety of active and passive vocabulary items.

\section{G rammar in EFL textbooks}

This sub-dimension includes five criteria/ questions for evaluating grammar in the textbook. The mean values of the teachers' responses to the questions to do with evaluating the structural/ grammatical components in the EFL textbooks range between 2.5 and 3.3. In light of the previously identified cut-points, this means that all the criteria are represented to some extent in the textbook. From these results, it can be concluded that, according to teachers, the language focus boxes in the textbook provide clear explanations for the rules, enough examples for applying the grammatical items, the self-study pages consolidate the grammatical items and the grammar reference enhances the previously learned grammatical items.

\section{The four language skills}

This sub-dimension includes seven criteria/ questions for evaluating the four language skills in the textbooks. As shown in table 3, the mean values of the responses of the teachers to the questions to do with the evaluation of the four language skills in the textbooks, except for question 25, ranged between 2.9 and 3.17. This means that most of the criteria are represented to some extent in the textbook. The highest mean value (3.17) is given to the question $D o$ the reading texts in the CB include authentic language?, whereas the lowest mean value (2.01) is given to the question Do the writing scripts in the $C B$ provide students with enough help for improving their own writings? From these results, it can be concluded that the teachers saw that the four language skills in the textbooks were presented integratively and practiced in each unit in a variety of text types. Teachers also thought that listening materials were significant to practice the listening skill, the speaking skill is practiced through real life situations, and the reading and writing skills include authentic language.

\section{Evaluation of dimension two: activities and tasks}

This dimension includes ten criteria formulated as questions to guide teachers through the evaluation activities and tasks in the Omani EFL textbooks. Table 4 displays the descriptive statistics of the responses of the teachers to the questions included in this dimension.

As can be seen from Table 4, the mean values of the responses of the teachers to the questions range between 2.3 and 2.8. In light of the previously identified cut-points, this means that eight out of the ten criteria are reflected to some extent and only two questions/ criteria are reflected to a little extent. From these descriptive results, it can be concluded that the teachers involved in this evaluative study see that the activities and tasks included.

Table 4

Means and standard deviations of the items of the second dimension (activities and tasks)

\begin{tabular}{|c|c|c|c|}
\hline Activities and Tasks in Textbooks & $\mathrm{N}$ & Mean & SD \\
\hline Do the activities/ tasks in the SB help students use the language communicatively? & 73 & 2.84 & .700 \\
\hline Do the activities/ tasks in the SB help improve the four language skills? & 70 & 2.80 & 672 \\
\hline Do the learning strategy boxes in the SB provide opportunities for students to reflect on 'how to learn'? & 73 & 2.78 & .731 \\
\hline Do the activities/ tasks in the SB promote students' critical thinking? & 73 & 2.72 & .750 \\
\hline $\begin{array}{l}\text { Do the projects in the SB help students learn different research skills such as collecting, analyzing data and } \\
\text { presenting findings? }\end{array}$ & 73 & 2.71 & .920 \\
\hline $\begin{array}{l}\text { Are the vocabulary activities/ tasks in the SB effective ways to help students learn, recycle and retain } \\
\text { words? }\end{array}$ & 73 & 2.65 & 671 \\
\hline Do the self-study activities/ tasks at the end of each unit in the SB promote learner autonomy? & 73 & 2.65 & .916 \\
\hline Do the club corner magazines in the SB provide students with opportunities for independent learning? & 73 & 2.46 & .944 \\
\hline Do the reflection activities/ tasks in the SB help students reveal their true understanding? & 73 & 2.42 & .926 \\
\hline Do the learning journals in the SB help students reflect on their own progress? & 73 & 2.26 & .928 \\
\hline
\end{tabular}


in the textbook help students use the language communicatively, promote their critical thinking, improve their language skills and help them learn and recycle words. It can also be concluded that the self-study activities, the learning strategy boxes and the projects included in the textbook promote the learners' autonomy and provide them with opportunities on how to collect, analyse data and present findings.

\section{Evaluation of dimension three: non-textual components}

This dimension includes seven criteria presented in the form of questions to guide teachers to evaluate the non-textual components in the Omani EFL textbooks. Non-textual components incorporate the layout, the covers, the blurb, the pictures, shape, diagrams, etc. Table 5 , displays the descriptive statistics of the responses of the teachers to the questions included in this dimension. The mean values of the responses of the teachers range between 2.8 and 3.4. This means that all the evaluative criteria are to some extent reflected in the textbooks. From these results, it can be concluded that the teachers involved in this evaluative study perceive the layout and design of the textbook as interesting, the title appealing, the blurb informative and the size of the textbook appropriate. The teachers also think that pictures, diagrams and tables in the textbooks are clear and help students to understand and conduct the required tasks and activities.

\section{Teachers' evaluation of grade $10 \mathrm{EFL}$ textbooks according to gender and teaching experience}

Tables 6 and 7 display the data related to the comparison of the teachers' evaluation of EFL textbooks according to gender and length of teaching experience respectively.

There was no statistically significant difference between the evaluation of the teachers due to gender (see Table 6). This can be attributed to the fact that gender traits have nothing to do with judging the usefulness and clarity of the Omani EFL textbooks. They also have the same vision as to the components of the textbooks.

Concerning the teaching experience variable, table 7, displays the results of teachers' evaluation of grade ten textbooks in terms of their different years of experience.
There was no statistically significant difference between teachers' evaluation of grade ten textbooks due to their years of experience. Teachers of different years of experience gave nearly the same answers to the questions/ criteria while evaluating the textbook. This may be attributed to the fact that there is no influence of the years of teachers' experience on responding to the questions in the evaluative checklist applied to the Omani EFL textbooks. It may also indicate that teachers have the same perceptions for the different components in the EFL textbooks.

\section{Analysis of qualitative data}

As mentioned earlier, while describing the research instrument, the evaluation checklist includes an open-ended question. Teachers' responses to the open-ended question were divided into two parts: (1) whether involving teachers in the process of textbook evaluation is professionally useful, and (2) the justifications of the usefulness of such involvement. A nalysis of the data shows that only 55 teachers out of $73(75 \%)$ answered the open-ended question. Female teachers represent the highest percentage, which is $41.1 \%$ compared with male teachers, which is $34.2 \%$.

The frequency and percentage data of teachers' answers to Part 1 of the question Do you think that involving teachers in the process of textbook evaluation is professionally useful? Why? shows that all the 55 teachers who answered the open-ended question think that involving teachers in the process of textbook evaluation is professionally useful. Furthermore, some of them added that it would be useful if teachers were involved in advance during the stage of textbook preparation and given the chance to suggest topics, activities and methods of teaching. This suggests that the majority of teachers were ready and eager to participate in any process of EFL textbook evaluation conducted by the Ministry of Education. 
Table 5

M eans and standard deviations of the items of the third dimension (non-textual components)

\begin{tabular}{|c|c|c|c|}
\hline The non-textual components in textbooks & $\mathrm{N}$ & Mean & SD \\
\hline A re the pictures in the CB \& SB clear, attractive, catchy and appropriate? & 73 & 3.46 & .625 \\
\hline A re the diagrams in the CB \& SB clear enough to serve their aims? & 73 & 3.30 & .616 \\
\hline Is the layout and design of both CB \& SB interesting? & 73 & 3.30 & .739 \\
\hline Is the title cover of both $\mathrm{CB} \& \mathrm{SB}$ appealing? & 73 & 3.28 & .588 \\
\hline Are the tables in the CB \& SB clear and useful to do tasks? & 73 & 3.20 & .725 \\
\hline Is the size of the CB \& SB appropriate? & 73 & 2.83 & .041 \\
\hline Is the blurb on the back cover of both CB \& SB informative? & 72 & 2.81 & .827 \\
\hline Total & & 3.17 & .594 \\
\hline
\end{tabular}

Table 6

t-test results of teachers' evaluation of grade ten EFL textbooks by gender

\begin{tabular}{lrrrrrr}
\multicolumn{7}{c}{ grade ten EFL textbooks by gender } \\
\hline Gender & $\mathrm{N}$ & Mean & $\mathrm{SD}$ & $\mathrm{t}$ & $\mathrm{df}$ & $\mathrm{p}$ \\
\hline Male & 35 & 2.855 & .358 & & & \\
& & & & -1.114 & 71 & .269 \\
Female & 38 & 2.946 & .337 & & & \\
\hline \multicolumn{7}{c}{ Table 7 }
\end{tabular}

Table 7

ANOVA results for teachers' evaluation of grade ten EFL textbooks with respect to teaching experience

\begin{tabular}{|c|c|c|c|c|c|}
\hline $\begin{array}{l}\text { Source of } \\
\text { variance }\end{array}$ & $\begin{array}{l}\text { Sum of } \\
\text { Squares }\end{array}$ & $d f$ & $\begin{array}{l}\text { Mean } \\
\text { Square }\end{array}$ & $F$ & p. \\
\hline $\begin{array}{l}\text { Between } \\
\text { Groups }\end{array}$ & .454 & 4 & .114 & & \\
\hline $\begin{array}{l}\text { Within } \\
\text { Groups }\end{array}$ & 8.235 & 68 & .121 & .938 & .447 \\
\hline Total & 8.689 & 72 & & & \\
\hline
\end{tabular}

In responding to Part 2, which includes their justifications for being involved in the evaluation process, teachers mentioned that they were more familiar than anyone else with the textbook, and more aware of students' needs and interests. Therefore, they believe that involving them in the process of textbook evaluation would:

1. Develop their experience in a way that helps them suggest the most useful language input to their students.

2. Determine how the textbook should be dealt with and what the best teaching methods are.

3. Enable them to suggest some adaptation while using the textbook according to different teaching situations as well as adapting the teaching methods according to the students' levels and abilities.

4. Widen their knowledge of textbook selection, preparation and evaluation.

\section{Summary and Conclusion}

This study was an attempt to involve EFL teachers in the process of textbook evaluation. The researchers reviewed the related literature, introduced different definitions of the term 'textbook', and discussed the role of text- books in ELT, and enumerated the reasons behind the need to evaluate textbooks. The main tool of the study (i.e. the evaluation checklist) was developed, validated and applied to 73EFL Omani male and female teachers. The analysis of teachers' responses to the evaluation questions in the checklist revealed that the EFL textbooks for grade ten of the Basic Education stage match the evaluation criteria the teachers used during the evaluation process to some extent.

Similar results that supported textbooks were provided by Al-Hajailan (1999), Peyaway (1992), and Al Amri (2008). Al-Hajailan, for example, showed support for the textbook's appearance, accompanying materials, and academic content. It was also found that there was no statistically significant difference be tween female and male teachers as to the evaluation of the textbooks due to gender or length of teaching experience. In addition, it was found that some teachers stressed the need for an ongoing formative evaluation of the textbooks before generalizing their use. Finally, teachers mentioned the importance of evaluating the other EFL materials related to the textbooks, such as teacher's guide, audio and video cassettes, and picture and word cards (see also Al-Hosni 2006 and AlMushaifri, 2006). Furthermore, there is a need in future studies to evaluate different aspects of the curriculum (see for example, Brown, 1997; Al-Akloby, 2001; Al Amri, 2003; Dow, 2004; Decio, 1996; Al-Darwish, 2006; and Peyawary, 1992).

The recommendations include: (1) conducting an evaluation process of all EFL textbooks using the checklist developed in this study, (2) involving all teachers in the evaluation process, (3) conducting in-service training workshops about textbook evaluation especially for novice teachers, (4) including an evaluation list at the end of each unit in the 
textbook to be filled out by the teacher, (5) involving students in the process of textbook evaluation, and (6) offering a course about textbook evaluation in the EFL teacher education program of the College of Education at Sultan Qaboos University.

\section{REFEREN CES}

Al Amri, A. (2008). Textbook evaluation: An evaluation of the sixth grade English language textbook for Saudi boys school. Unpublished MA thesis, King Saud University.

Al Amri, I. (2003). Textbook evaluation: A n evaluation plan. Sultan Qaboos University, Retrieved January 5, 2011, from www.squ.edu.om.

Al Mushaifri, S. (2006). Sultanate of O man's experience in evaluating the current educational curriculum in the BE. Unpublished MEd thesis, University of Hull.

Al-A kloby, S. (2001). Teaching and learning English vocabulary in Saudi Arabian Public Schools: An exploratory study of some possible reasons behind students' failure to learn English vocabulary. Published PhD dissertation, University of Essex.

Al-Darwish, S. (2006). A n investigation of teachers' perceptions of the English language curriculum in Kuwaiti elementary schools. Published PhD dissertation, University of Denver.

Al-Hajailan, T. (1999). Evaluation of English as a foreign language textbook for third grade secondary boys' schools in Saudi Arabia. Published PhD dissertation, Mississippi State University.

Al-Hosni, T. (2006). Omani EFL teachers' involvement in curriculum development: perceptions and practices. Unpublished MEd Thesis, Sultan Qaboos University.

Ansary, H. \& Babaii, E. (2002). Universal characteristics of EFL/ ESL textbooks: A step towards systematic textbook evaluation. The internet TESL Journal, 8 (2). Retrieved February, 20, 2013 from: www.citeulike.org.

Breen, M. and Candlin, C. (1987). Which materials? A consumer's and designer's guide in ELT textbooks and materials: Problems in evaluation and development. London, Modern English Publication in association with the British Council.
Brown, J. (1997). Textbook evaluation form. Journal of the Japan A ssociation for Language Teaching (JALT Journal). Issue 21.10; October 1997. Retrieved August, 4, 2013, from: www.jalt-publications.org.

Cisar, S. (2002). Standards-based textbook evaluation guide: Foreign language standards implementation guide. Indiana University, Bloomington Indiana. Retrieved December, 9, 2013, from: http:/ / www.docstoc.com.

Collins Cobuild English Dictionary (1995). The COBUILD Series from the Bank of English. England.

Cunningsworth, A. (1995). Choosing your course book. Los Angeles: Heinle and Heinle Publishers.

Decio, G. (1996). A ssessment of the evolution of grammar practice in ESL/EFL textbooks from 1960 until 1996. Unpublished PhD dissertation, Purdue University.

Dougill, J. (1987). Not so obvious. In L. Sheldon (Ed.) ELT textbooks and materials: Problems in evaluation and development. ELT documents, 126, Modern English Publications in association with The British Council.

Dow, D. (2004). Evaluating classroom teaching materials. Billy Graham Centre, Wheaton College. Retrieved June, 8, 2012, from http:/ / www2.wheaton.edu.

Ellis, R. (1997). The empirical evaluation of language teaching materials. ELT Journal, January, 51 (1), 36-42.

English Dictionary with multi-lingual search (2007). Retrieved September 12, 2012, from: www.allwords.com.

Gomes de M atos, F. (2000). TESOLers as textbook evaluators: An interdisciplinary checklist. BRAZ-TESO L N ewsletter, 16-18.

Gómez-Rodríguez, L. F. (2010). English textbooks for teaching and learning English as a foreign language: D o they really help to develop communicative competence? Retrieved June, $7, \quad 2013$, from: http:/ / educacionyeducadores.unisabana.e du

Hutchinson, T. \& Torres, E. (1994). The textbook as agent of change. ELT Journal, 48 (4), 315-328. 
Hutchinson, T. \& Waters, A . (1987). English for specific purposes: A learning-centered approach. Cambridge: Cambridge University Press.

Kulm, G., Roseman, J., \& Treistman, M. (1999). A benchmarks-based approach to textbook evaluation. Science Books and Films, $35,147-153$.

Lawrence, W. (2011). Textbook evaluation: A framework for evaluating the fitness of the $\mathrm{H}$ ong Kong new secondary school curriculum. Retrieved November, 20, 2013, from: http:/ / asian-efl-journal

Matthews, A . (1985). Choosing the best available textbook. In A. Matthews, M. Spratt, and L. Dangerfield (Eds.). At the chalkface. (pp. 202-206). London: Edward Arnold. Ministry of Education, Sultanate of Oman. (1996). Basic education in Oman. Retrieved September, 2, 2010 from: www.moe.gov.om

Peyawary, A. (1992). The appropriateness of the vocabulary and the topics contained in the grades 7-12 English as a foreign language textbooks in A fghan M ujahideen high schools in Pakistan to the objectives of current A fghan education. Published M.Ed. thesis, University of Manitoba (Canada).

Portway, P. S. \& Lane, C (1997). Guide to teleconferencing and distance learning (3rd ed.).
New York: Applied Business Telecommunication.

Tanner, D. (1988). The textbook controversies, in L.N. Tanner (ed.) Critical issues on curriculum (Eighty-Seventh Yearbook of the $\mathrm{Na}$ tional Society for the study of education, part I), N ational Society for the study of Education, Chicago.

The Free Dictionary, (2014). Retrieved January, 9, 2014 from: http:/ / ar.thefreedictionary

Tomlinson, B. (2005). The future for ELT materials in Asia. Electronic Journal of Foreign Language Teaching, 2(2), 5-13.

Williams, D. (1983). Developing criteria for textbook evaluation. ELT Journal, 37 (3), 251-255.

Williams, R. (1981). A procedure for ESP textbook analysis and evaluation on teacher education courses. The ESP Journal, 1 (29), 155-162

Yen, Y. (2000). Identity issues in EFL and ESL textbooks: A sociocultural perspective. Published PhD dissertation, Ohio State University.

Zabawa, J. (2001). Criteria for FCE textbook evaluation: An attempt at Questionnaire formulation. Zeszyt, (42) 161-169 